\title{
Deteksi Virus Pada Tanaman Mentimun Di Jawa Barat
}

\author{
(Virus Detection on Cucumber Plants in West Java) \\ Nur Unsyah Laili ${ }^{1}$, dan Tri Asmira Damayanti $1^{*}$ \\ ${ }^{1}$ Departemen Proteksi Tanaman, Fakultas Pertanian, Institut Pertanian Bogor \\ Jl. Kamper, Kampus IPB Dramaga, Bogor 16680 Telepon/Faks: 0251-8629364/0251-8629362 \\ *Email korespondensi: triadys@apps.ipb.ac.id
}

Diterima 25 Maret 2019/Disetujui 10 Mei 2019

\begin{abstract}
The virus-like symptoms were observed on cucumber cultivation in West Java. However, it was difficult to differentiate the virus species based on visual symptoms. The research aimed to updating the viruses data which infect cucumber in Bogor, Karawang, and Subang regencies, West Java. The virus frequency was determined by dot immunobinding assay (DIBA) method using Cucumber mosaic virus (CMV), Cucurbit aphid borne yellow virus (CABYV), Cucurbit green mottle mosaic virus (CGMMV), Papaya ringspot virus (PRSV), Squash mosaic virus (SqMV), Watermelon mosaic virus (WMV), and Zucchini yellow mosaic virus (ZYMV) antisera. Detection of nucleic acids of the newly predominant viruses was conducted by reverse transcription polymerase chain reaction (RT-PCR)/PCR. The results showed that the frequency of CMV, CABYV, CGMMV, PRSV, SqMV, WMV, and ZYMV in Bogor were up to 98\%, 100\%, 86\%, 0\%, 8\%, 32\%, and 6\%, while in Subang were up to $86 \%, 100 \%, 88 \%, 2 \%, 8 \%, 60 \%$, and 46\%, and Karawang were $100 \%, 100 \%, 98 \%, 14 \%$, 72\%, 68\%, and 64\%, respectively. $C M V, C A B Y V$, and CGMMV were the most common viruses detected in three regencies, while PRSV only detected on samples from Subang and Karawang. These indicating the existence of those viruses and their distribution in three regencies. RT-PCR using either spesific primer or universal primer unable to amplified CGMMV, however successfully confirmed the existence of PRSV strain P, Polerovirus, and Begomovirus.
\end{abstract}

Keywords: Cucurbitaceae, Geminiviridae, Luteoviridae, Potyviridae, Tobamovirus

\section{ABSTRAK}

Gejala infeksi virus banyak ditemukan di pertanaman mentimun di Jawa Barat. Namun, sulit membedakan virus penyebab hanya berdasarkan pengamatan gejala visual. Penelitian ini bertujuan untuk pemutakhiran data virus yang menginfeksi mentimun di Kabupaten Bogor, Karawang dan Subang, Jawa Barat. Sampel tanaman bergejala dikoleksi dari tiap lokasi. Frekuensi virus ditentukan secara serologi dengan metode DIBA (dot immunobinding assay) menggunakan antiserum Cucumber mosaic virus (CMV), Cucurbit aphid borne yellow virus (CABYV), Cucurbit green mottle mosaic virus (CGMMV), Papaya ringspot virus (PRSV), Squash mosaic virus (SqMV), Watermelon mosaic virus (WMV), dan Zucchini yellow mosaic virus (ZYMV). Deteksi asam nukleat dilakukan terhadap virus baru yang dominan dengan reverse transcription polymerase chain reaction (RT-PCR)/PCR. Hasil deteksi menunjukkan bahwa frekuensi virus CMV, CABYV, CGMMV, PRSV, SqMV, WMV, dan ZYMV berturut-turut di Bogor mencapai 98\%, 100\%, 86\%, 0\%, 8\%, 32\%, dan 6\%, di Subang mencapai $86 \%, 100 \%, 88 \%, 2 \%, 8 \%, 60 \%$, and 46\%, dan di Karawang 100\%, 100\%, 98\%, 14\%, 72\%, 68\%, and 64\%. CMV, CABYV, and CGMMV were the most common viruses detected in three regencies, while PRSV only detected on samples from Subang and Karawang. RT-PCR/PCR menggunakan primer spesifik atau universal belum berhasil mendeteksi CGMMV dan WMV, namun berhasil mengonfirmasi keberadaan PRSV, Polerovirus, dan Begomovirus.

Kata kunci: Cucurbitaceae, Geminiviridae, Luteoviridae, Potyviridae, Tobamovirus

\section{PENDAHULUAN}

Mentimun (Cucumis sativus L.) merupakan komoditas sayuran dari famili labu-labuan (Cucurbitaceae) yang adaptasinya cukup luas (Moekasan et al., 2014). Tanaman ini berasal dari Benua Asia, yakni India dan dibudidayakan hampir di seluruh dunia (Rukmana 1994). Badan Pusat Statistik (2013) mencatat produksi mentimun di Indonesia tahun 2013 mencapai 256006 ton. Produksi mentimun ini menurun dibandingkan dengan tahun sebelumnya yang mencapai 511525 ton. Penurunan produksi tersebut salah satunya disebabkan oleh penyakit yang disebabkan oleh virus.

Sekitar 32 virus dilaporkan dapat menginfeksi tanaman Cucurbitacea diantaranya Cucurbit aphid borne yellow mosaic virus (CABYV), Cucumber green mottle mosaic virus (CGMMV), Cucumber mosaic virus (CMV), 
Papaya ringspot virus (PRSV), Squash mosaic virus (SqMV), Watermelon mosaic virus (WMV), dan Zucchini yellow mosaic virus (ZYMV) (Coutts dan Jones 2005; Ali et al. 2012). Selain virus-virus yang umum ditemukan, terdapat virus dari kelompok Begomovirus yang menyebabkan penyakit yang cukup penting pada mentimun (Shtayeh et al., 2010).

Diantara virus tersebut diatas CGMMV dan SqMV merupakan virus yang termasuk dalam daftar OPTK A1 dan A2, sedangkan CABYV belum banyak dilaporkan menginfeksi cucurbitaceae di Indonesia. PRSV-P dilaporkan pertama kali menginfeksi pepaya (Hidayat et al., 2012), namun belum diketahui menginfeksi tanaman cucurbitacea, termasuk mentimun. Virus-virus ini di lapangan perlu selalu dipantau keberadaannya di lapangan, mengingat tanaman cucurbitacea seperti mentimun merupakan tanaman sayuran penting.

Peningkatan infeksi dan munculnya virus baru pada tanaman mentimun di Indonesia kemungkinan disebabkan oleh adanya importasi benih dari negara lain. Sehingga perlu dilakukan pemutakhiran tentang penyakit virus secara berkala untuk mengetahui identitas, sebaran, dan frekuensinya di lapangan.

\section{BAHAN DAN METODE}

Survei dan pengambilan sampel tanaman mentimun yang bergejala dilakukan di pertanaman mentimun di Kabupaten Bogor; sampel diambil dari desa Bojong (BBO), Sindang Barang (SBO), dan Petir (SPE), Kabupaten Subang; Desa Marjim (SMA), Tanjung Baru (STB), dan Pungangan (SPU), dan Kabupaten Karawang; Desa Kaceot (KKA), Jatimulya (KJA), dan Kutakarya (KKA), Jawa Barat. Deteksi virus dilakukan di Laboratorium Virologi Tumbuhan Departemen Proteksi Tanaman, Fakultas Pertanian, Institut Pertanian Bogor.

\section{Pengambilan Sampel Tanaman Mentimun}

Sampel tanaman mentimun yakni daun yang bergejala diambil sebanyak 50 sampel dari tiap lokasi. Deskripsi gejala dan dokumentasi menggunakan kamera digital dilakukan pada masing-masing sampel. Sampel dari semua lokasi dibawa ke Laboratorium dan disimpan pada suhu $-80{ }^{\circ} \mathrm{C}$.

\section{Metode Penelitian}

Frekuensi virus ditentukan secara serologi menggunakan metode Dot immunobanding assay (DIBA) dengan antiserum CABYV, CGMMV, CMV, PRSV, SqMV, WMV, dan ZYMV (DSMZ, Jerman). Sedangkan amplifikasi DNA dilakukan dengan PCR atau RT-PCR menggunakan primer target virus atau primer universal.

\section{Penghitungan Frekuensi Virus}

Frekuensi virus ditentukan berdasarkan uji serologi dengan metode Dot immunobinding assay (DIBA) menggunakan rumus sebagai berikut:

$$
\begin{array}{ll} 
& \mathrm{FV} \quad=\frac{\mathrm{n}}{\mathrm{N}} \times 100 \% \\
\mathrm{FV} & =\text { Frekuensi virus }(\%) \\
\mathrm{n} & =\text { Jumlah tanaman positif terdeteksi virus } \\
\mathrm{N} & =\text { Jumlah seluruh tanaman yang diuji }
\end{array}
$$

\section{Dot Immunobinding Assay (DIBA)}

Metode DIBA dilakukan sesuai metode yang digunakan oleh Asniwita et al. (2013). Deteksi dengan DIBA terdiri dari beberapa tahapan, yaitu blotting, blocking reaksi antibodi 1 , reaksi antibodi 2 , dan pewarnaan. Pada proses pewarnaan, membran direndam selama 5 menit dalam Alkalin Phosphatase buffer $\mathrm{pH} 9.5$ (yang mengandung nitro blue tetrazolium (NBT) dan bromo chloro indolyl phosphate (BCIP). Jika reaksi positif akan terjadi perubahan warna putih menjadi ungu pada membran nitroselulosa yang telah ditetesi cairan sap dan reaksi dapat dihentikan dengan merendam membran dengan $\mathrm{dH}_{2} \mathrm{O}$.

\section{Deteksi Asam Nukleat dengan Reverse-Transcription Polymerase Chain Reaction (RT-PCR)/PCR}

Metode deteksi virus dengan RT-PCR/PCR terdiri dari beberapa tahapan, yaitu ekstraksi RNA/DNA total, sintesis complementary DNA (cDNA), amplifikasi DNA target, dan visualisasi hasil amplifikasi.

Ekstraksi RNA/DNA total. Ekstraksi RNA/DNA total secara manual dilakukan dengan mengikuti metode CTAB (Doyle dan Doyle 1990). Sebanyak $0.1 \mathrm{~g}$ daun digunakan untuk mendapatkan RNA/DNA total. Pelet RNA/DNA total dilarutkan dalam $50 \mu \mathrm{L}$ air bebas nuklease.

Sintesis cDNA. Produk ekstraksi RNA total digunakan sebagai template untuk sitesis cDNA. Sintesis cDNA terjadi melalui transkripsi balik RNA menggunakan enzim transkriptase MmuLV (Moloney Murine Leukimia Virus). Molekul cDNA tersebut digunakan untuk cetakan pada proses PCR. Komposisi bahan reaksi transkripsi balik terdiri dari: bufer RT $2 \mu \mathrm{L}$, dNTP $10 \mathrm{mM} 0.50 \mu \mathrm{L}$, DTT 50 $\mathrm{mM} 0.35 \mu \mathrm{L}$, RNAse inhibitor (Thermoscientific) $0.35 \mu \mathrm{L}$, MmuLV (Thermo scientific) $0.35 \mu \mathrm{l}, \mathrm{dH}_{2} \mathrm{O} \mu \mathrm{L}$, oligo d(T) $0.75 \mu \mathrm{L}$, dan RNA total sebanyak $2 \mu \mathrm{L}$. Untuk sintesis cDNA dari genus Polerovirus menggunakan primer reverse Polerovirus (CPR). Reaksi RT diinkubasi berturut-turut pada suhu $65{ }^{\circ} \mathrm{C}$ selama 5 menit, $42{ }^{\circ} \mathrm{C}$ selama 60 menit, dan $70{ }^{\circ} \mathrm{C}$ selama 10 menit. Produk cDNA kemudian digunakan sebagai templat pada amplifikasi PCR.

RT-PCR/PCR. Amplifikasi DNA virus dilakukan dengan menggunakan pasangan primer untuk mengamplifikasi dan mendeteksi CGMMV dengan pasangan primer Tob-Uni 1-cpR (5'ATTTAAGTGGASGGAAAAVCACT-3') dan CGMMVcpF (5'-GATTCCTTATCCGAGAAAGTT-3') dengan amplikon berukuran $\pm 830 \mathrm{pb}$ (Letschert et al., 2002). Geminivirus diamplifikasi dengan primer SPG1 (5'CCCKGTGCGWRAATCCAT-3') dan SPG2 (5'- 
ATCCVAAYWTYCAGGGAGCTAA-3') dengan amplikon berukuran $\pm 900 \mathrm{pb}$ (Li et al., 2004). CABYV diamplifikasi dengan primer universal Polerovirus PL4F (5'GTCTACCTATTTBGGRTTNTGGAA-3') dan o3R (5'TGCGACAAATAGTTAATGAATACGGT-3') dengan amplikon berukuran $\pm 600 \mathrm{pb}$ (Correa et al., 2005). PRSV diamplifikasi dengan primer spesifik gen CP PRSV-PcpF (5'-TCGTGCCACTCAATCACAAT-3') dan PRSV-PcpR (5'-GTTACTGACATGCCGTCCA-3') dengan amplikon berukuran $\pm 470 \mathrm{pb}$ (Mohammed et al., 2012), sedangkan WMV diamplifikasi dengan primer universal Potyvirus MJ1 (5'-ATGGTHTGGTGTGYATHGARAAYGG-3') dan MJ2 (5'-TGCTGCKGCYTTCATYTG-3') dengan amplikon berukuran $\pm 320 \mathrm{pb}$ (Marie-Jeanne et al., 2000).

Amplifikasi cDNA/DNA total dilakukan dalam volume $25 \mu \mathrm{L}$ dengan komposisi reaktan sebagai berikut: $12.5 \mu \mathrm{L} 2 \mathrm{X}$ Go Taq Green (Thermo Scientific), masingmasing $1 \mu \mathrm{L} 10 \mu \mathrm{M}$ primer forward dan reverse, $1 \mu \mathrm{L}$ cDNA/DNA total dan $9.5 \mu \mathrm{L}$ air bebas nuklease. PCR dilakukan menggunakan program sesuai dengan rekomendasi masing-masing pasangan primer (Tabel 1).

Visualisasi DNA. Visualisasi DNA hasil amplikasi dilakukan pada elektroforesis gel agarosa $1.5 \%$. Agarosa sebanyak $0.3 \mathrm{~g}$ dicampur dengan $30 \mathrm{ml}$ buffer $0.5 \mathrm{x}$ TBE (Tris borate EDTA) dan dipanaskan dalam microwave selama 2 menit hingga tercampur rata, setelah gel hangat dituang ke dalam cetakan gel (gel tray) dan didiamkan selama \pm 30 menit hingga mengeras.

Sebanyak $5 \mu 1$ marker DNA dan $7 \mu 1$ DNA hasil PCR dimasukkan ke dalam sumuran gel dan dilakukan elektroforesis selama 50 menit pada tegangan 50 volt. DNA yang telah dielektroforesis lalu direndam dalam larutan ethidium bromida selama 15 menit. Visualisasi DNA dilakukan dibawah UV transiluminator dan didokumentasi dengan kamera digital.

\section{HASIL DAN PEMBAHASAN}

\section{Gejala Infeksi Virus pada Tanaman Mentimun di Lapangan}

Gejala infeksi virus dari lokasi pengambilan sampel bervariasi berupa mosaik pada daun, kuning, malformasi daun, vein banding, klorosis dan keriting pada daun (Gambar 1; Tabel 2). Gejala dominan pada pertanaman mentimun di Bogor yaitu mosaik dan ujung-ujung daun mengeriting. Gejala pada pertanaman mentimun di Karawang menunjukkan gejala yang hampir sama dengan mentimun di Subang, namun mengalami penebalan daun.

\section{Frekuensi Virus}

Frekuensi virus berdasarkan hasil DIBA dari 150 sampel yang diuji menunjukkan tanaman positif terinfeksi CABYV, CGMMV, CMV, PRSV, SqMV, WMV, dan ZYMV dengan frekuensi masing-masing sebesar $100 \%$, $86 \%, 98 \%, 0 \%, 8 \%, 32 \%$, dan 6\%. Frekuensi CGMMV, CMV, PRSV, SqMV, WMV, dan ZYMV di Kabupaten Karawang berturut-turut adalah 98\%, 100\%, 14\%, 72\%, $68 \%$, dan $64 \%$, dan di Kabupaten Subang berturut-turut adalah $88 \%, 86 \%, 2 \%, 8 \%, 60 \%$,dan $46 \%$. Frekuensi CABYV pada ketiga lokasi menunjukkan paling tinggi, dan yang terendah adalah PRSV di Kabupaten Karawang (2\%) dan Subang (14\%) (Tabel 3). PRSV tidak terdeteksi pada sampel dari Kabupaten Bogor.

Tabel 1. Program PCR untuk mendeteksi virus pada mentimun

\begin{tabular}{llllllc}
\hline \multirow{2}{*}{ Target } & \multicolumn{5}{c}{ Kondisi PCR } & \multirow{2}{*}{$\sum$ Siklus } \\
\cline { 2 - 5 } & Predenaturasi & Denaturasi & Annealing & Elongasi & Ekstensi akhir & \\
\hline CGMMV & $94^{\circ} \mathrm{C} / 5 \mathrm{~min}$ & $94^{\circ} \mathrm{C} / 1 \mathrm{~min}$ & $60^{\circ} \mathrm{C} / 45 \mathrm{det}$ & $72^{\circ} \mathrm{C} / 1 \mathrm{~min}$ & $72^{\circ} \mathrm{C} / 5 \mathrm{~min}$ & 35 \\
Geminivirus & $94^{\circ} \mathrm{C} / 5 \mathrm{~min}$ & $94^{\circ} \mathrm{C} / 1 \mathrm{~min}$ & $50^{\circ} \mathrm{C} / 1 \mathrm{~min}$ & $72^{\circ} \mathrm{C} / 1 \mathrm{~min}$ & $72^{\circ} \mathrm{C} / 7 \mathrm{~min}$ & 30 \\
Polerovirus & $95^{\circ} \mathrm{C} / 5 \mathrm{~min}$ & $95^{\circ} \mathrm{C} / 1 \mathrm{~min}$ & $45^{\circ} \mathrm{C} / 1 \mathrm{~min}$ & $72^{\circ} \mathrm{C} / 1 \mathrm{~min}$ & $72^{\circ} \mathrm{C} / 10 \mathrm{~min}$ & 35 \\
PRSV & $94^{\circ} \mathrm{C} / 5 \mathrm{~min}$ & $94^{\circ} \mathrm{C} / 30 \mathrm{det}$ & $50^{\circ} \mathrm{C} / 1 \mathrm{~min}$ & $72^{\circ} \mathrm{C} / 1 \mathrm{~min}$ & $71^{\circ} \mathrm{C} / 7 \mathrm{~min}$ & 35 \\
WMV & $94^{\circ} \mathrm{C} / 5 \mathrm{~min}$ & $94^{\circ} \mathrm{C} / 4 \mathrm{~min}$ & $53^{\circ} \mathrm{C} / 1 \mathrm{~min}$ & $72^{\circ} \mathrm{C} / 1 \mathrm{~min}$ & $75^{\circ} \mathrm{C} / 5 \mathrm{~min}$ & \\
\hline
\end{tabular}

Tabel 2. Variasi gejala infeksi virus pada tanaman mentimun di Jawa Barat

\begin{tabular}{|c|c|c|c|c|c|c|c|}
\hline \multirow{2}{*}{ Lokasi } & \multicolumn{6}{|c|}{ Tipe gejala $^{\mathrm{a}}$} & \multirow[b]{2}{*}{ Kultivar } \\
\hline & $\mathrm{M}$ & MK & $\mathrm{K}$ & VB & $\mathrm{VC}$ & $\mathrm{Kdl}$ & \\
\hline Bogor & $\sqrt{ }$ & $\sqrt{ }$ & $\sqrt{ }$ & $\sqrt{ }$ & & & Bandana, Wulan, Bulan \\
\hline Karawang & $\sqrt{ }$ & $\sqrt{ }$ & $\sqrt{ }$ & $\sqrt{ }$ & & $\sqrt{ }$ & Bandana, Etana \\
\hline Subang & $\sqrt{ }$ & $\sqrt{ }$ & $\sqrt{ }$ & $\sqrt{ }$ & & & Labana, Sabana, Bandana \\
\hline
\end{tabular}

${ }^{\mathrm{a})} \mathrm{M}=$ Malformasi, $\mathrm{MK}=$ mosaik, $\mathrm{K}=$ kuning, $\mathrm{VB}=$ vein banding, $\mathrm{VC}=$ vein clearing, $\mathrm{Kdl}=$ kerdil 

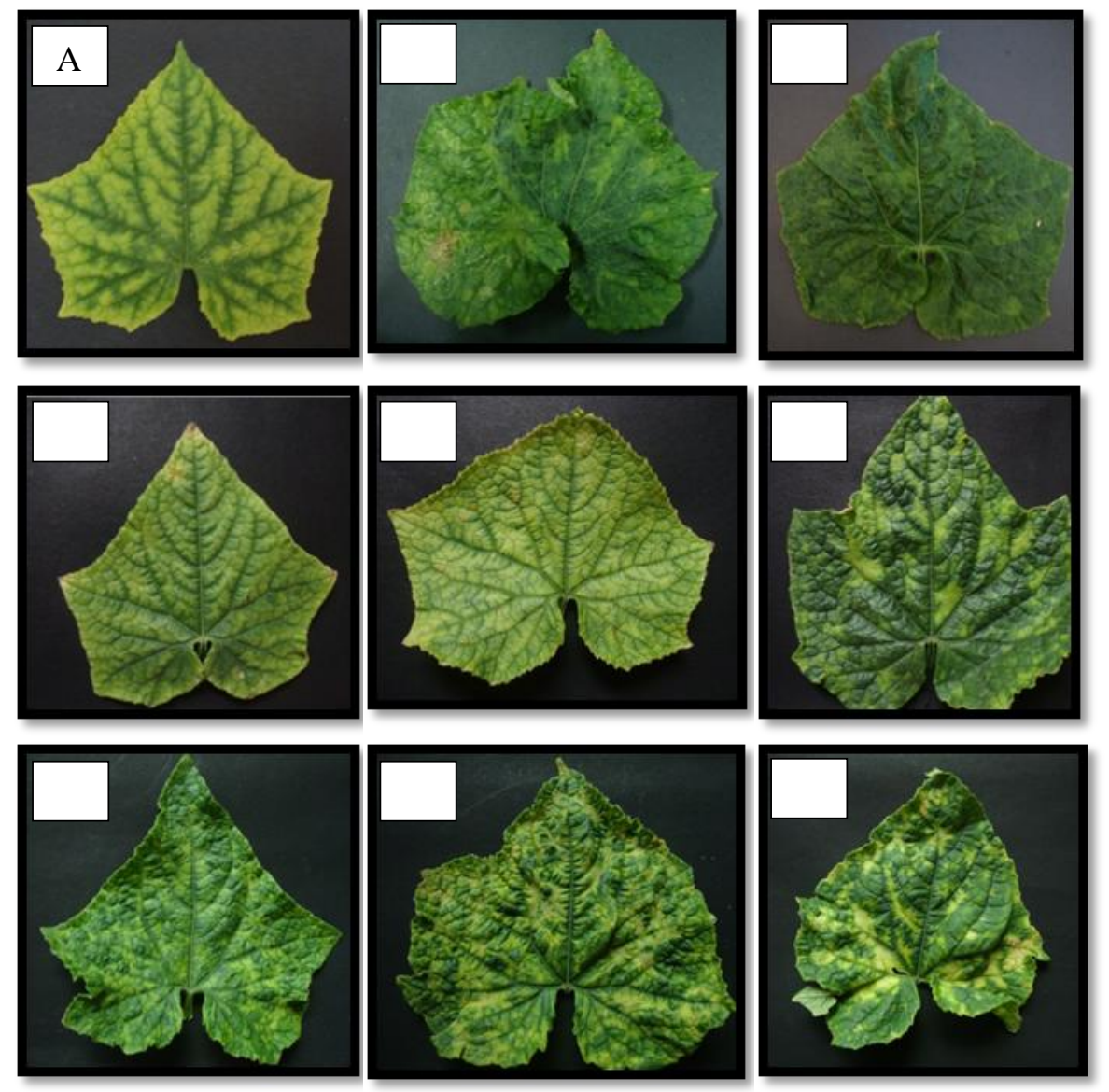

Gambar 1. Gejala dominan infeksi virus pada tanaman mentimun di Kabupaten Bogor (A-C), Karawang (D-F), dan Subang (G-I). (A) kuning disertai vein banding, (B dan C) malformasi daun disertai keriting, (D) klorosis disertai penebalan daun, (E) klorosis, (F dan G) mosaik, (H) klorosis dan malformasi, dan (I) mosaik dan kerdil

Tabel 3 Frekuensi Virus Berdasarkan Hasil DIBA

\begin{tabular}{|c|c|c|c|c|c|c|c|c|}
\hline \multirow{3}{*}{$\begin{array}{l}\text { Antiserum virus } \\
\text { CABYV }\end{array}$} & \multicolumn{6}{|c|}{ Frekuensi virus ${ }^{\mathrm{a}}(\%)$ dari tiap lokasi } & \multirow{2}{*}{\multicolumn{2}{|c|}{ Total (\%) }} \\
\hline & \multicolumn{2}{|c|}{ Bogor } & \multicolumn{2}{|c|}{ Subang } & \multicolumn{2}{|c|}{ Karawang } & & \\
\hline & $50 / 50$ & $(100)$ & $50 / 50$ & $(100)$ & $50 / 50$ & (100) & $150 / 150$ & $(100)$ \\
\hline CGMMV & $43 / 50$ & (86.0) & $44 / 50$ & $(88.0)$ & $49 / 50$ & (98.0) & $136 / 150$ & (90.6) \\
\hline CMV & $49 / 50$ & (98.0) & $43 / 50$ & $(86.0)$ & $50 / 50$ & (100) & $142 / 150$ & (94.6) \\
\hline PRSV & $0 / 50$ & $(0.0)$ & $1 / 50$ & (2.0) & $7 / 50$ & (14.0) & $8 / 150$ & (5.3) \\
\hline SqMV & $4 / 50$ & (8.0) & $4 / 50$ & $(8.0)$ & $36 / 50$ & (72.0) & $44 / 150$ & (29.3) \\
\hline WMV & $16 / 50$ & $(32.0)$ & $30 / 50$ & $(60.0)$ & $34 / 50$ & $(68.0)$ & $80 / 150$ & (53.3) \\
\hline ZYMV & $3 / 50$ & $(6.0)$ & $23 / 50$ & $(46.0)$ & $32 / 50$ & $(64.0)$ & $58 / 150$ & (38.7) \\
\hline
\end{tabular}

${ }^{a}$ Frekuensi virus $=\mathrm{n} / \mathrm{N} \times 100 \% ; \mathrm{n}=$ jumlah tanaman positif terdeteksi virus, $\mathrm{N}=$ total tanaman yang diuji.

\section{Infeksi Campuran}

Berdasarkan hasil deteksi serologi, terdeteksi adanya infeksi campuran pada sebagian tanaman mentimun. Infeksi campuran CABYV, CGMMV, dan CMV merupakan yang paling dominan dideteksi di Kabupaten Bogor dan Subang. Infeksi campuran lainnya terdeteksi pada 22 sampel tanaman (15\%) dari Kabupaten Bogor, 27 sampel tanaman (18\%) dari Kabupaten Subang, dan 53 sampel tanaman (35\%) dari Kabupaten Karawang (Tabel 4).

\section{Amplifikasi DNA}

Pita DNA PRSV asal Karawang teramplifikasi dengan ukuran $\pm 470 \mathrm{pb}$ (Gambar 2a). DNA Polerovirus asal Subang berukuran $\pm 400 \mathrm{pb}$ (Gambar 2b) dan amplifikasi DNA Geminivirus asal Subang dan Karawang berukuran \pm $900 \mathrm{pb}$ (Gambar 2c). WMV dan CGMMV belum berhasil teramplifikasi dengan primer universal (data tidak ditampilkan), sehingga perlu dideteksi lebih lanjut dengan primer spesifik virus untuk mengkonfirmasi hasil deteksi serologi. 
Tabel 4. Frekuensi infeksi tunggal dan infeksi campuran virus (\%)

\begin{tabular}{|c|c|c|c|}
\hline \multirow{2}{*}{ Tipe infeksi } & \multicolumn{3}{|c|}{ Lokasi Pengambilan Sampel } \\
\hline & Bogor & Subang & Karawang \\
\hline \multicolumn{4}{|l|}{ Infeksi tunggal $^{\mathrm{a}}$} \\
\hline A & 1 & 0 & 0 \\
\hline \multicolumn{4}{|l|}{ Infeksi ganda $^{a}$} \\
\hline $\mathrm{AG}$ & 0 & 1 & 0 \\
\hline $\mathrm{AM}$ & 3 & 1 & 0 \\
\hline $\mathrm{AZ}$ & 0 & 1 & 0 \\
\hline AGM & 23 & 16 & 2 \\
\hline AGW & 0 & 3 & 0 \\
\hline AGZ & 0 & 2 & 0 \\
\hline AMW & 2 & 0 & 0 \\
\hline AGMP & 0 & 0 & 5 \\
\hline AGMS & 2 & 2 & 8 \\
\hline AGMW & 10 & 6 & 0 \\
\hline AGMZ & 1 & 0 & 2 \\
\hline AMWZ & 1 & 2 & 1 \\
\hline AMPWZ & 0 & 1 & 0 \\
\hline AGMPS & 0 & 0 & 5 \\
\hline AGMSW & 2 & 0 & 3 \\
\hline AGMWZ & 1 & 12 & 9 \\
\hline AGMSWZ & 0 & 2 & 17 \\
\hline AGMPSWZ & 0 & 0 & 3 \\
\hline
\end{tabular}
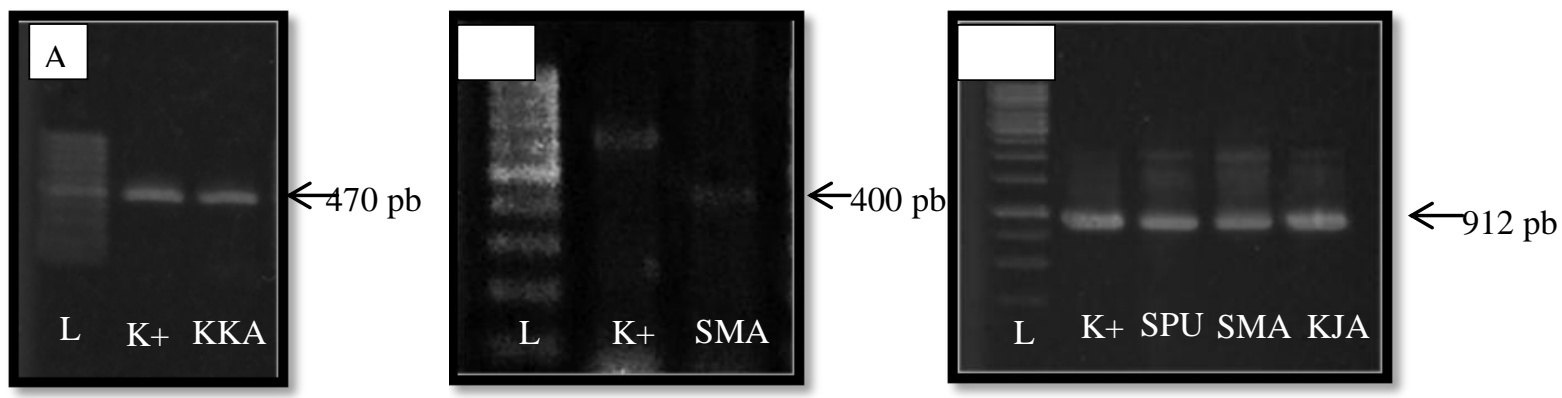

Gambar 2. Amplifikasi DNA PRSV (a), Polerovirus (b), dan Geminivirus (c). Ukuran DNA ditunjukkan dengan panah. L = penanda DNA $100 \mathrm{pb}$ (a dan b), $1 \mathrm{~kb}$ (c) (Thermo scientific), K+ = kontrol positif, KKA = sampel asal Karawang desa Kutakarya, SMA = sampel asal Subang desa Marjim, SPU = sampel asal Subang desa Pungangan, SMA = sampel asal Subang desa Marjim, KJA = sampel asal Karawang desa Jatimulya

Gejala penyakit yang ditemukan di lapangan berupa mosaik pada daun, klorosis, malformasi daun, vein banding, keriting, dan kuning. Gejala mosaik yang dominan ditemukan bercampur dengan permukaan daun yang tidak rata, malformasi, dan klorosis. Selain menyebabkan mosaik pada daun, infeksi virus juga menyebabkan penurunan kuantitas dan kualitas buah.

Infeksi campuran pada tanaman mentimun terdeteksi berdasarkan deteksi serologi. Interaksi virus pada infeksi campuran dapat berupa interaksi sinergis dan antagonis. Interaksi sinergis adalah infeksi campuran antara dua atau lebih virus yang meningkatkan replikasi dari satu atau kedua virus, dan menyebabkan gejala yang lebih parah dibandingkan infeksi tunggal (Zhang et al., 2001; Syller, 2012). Interaksi tersebut juga meningkatkan kerusakan pada tanaman terutama pada kultivar rentan sehingga meningkatkan kehilangan hasil panen (Zhang et al. 2001; Syller, 2012).

Interaksi antara ZYMV dengan CABYV atau CMV pada mentimun merupakan interaksi sinergis (Poolpol dan Inoue 1986). Kehilangan hasil panen pada mentimun dilaporkan terjadi akibat infeksi campuran oleh CMV dan Potyvirus (Moradi dan Jafarpur 2010). Interaksi antagonis adalah interaksi yang menyebabkan hanya satu virus yang memperoleh keuntungan dan menurunkan aktivitas virus lainnya (Syller, 2012). Infeksi campuran pada satu tanaman mentimun kemungkinan terjadi karena penyebaran virus oleh serangga vektor kutudaun (CMV, CABYV, PRSV, WMV, ZYMV), kumbang (SqMV), dan penggunaan benih yang dihasilkan dari tanaman sakit. Kecuali CGMMV dan CABYV, lima virus lainnya diketahui terbawa benih. Infeksi campuran menyebabkan variasi gejala yang berbeda dari 
infeksi tunggal masing-masing virus, sehingga sulit menentukan virus penyebab hanya berdasarkan pengamatan gejala saja.

RT-PCR DNA PRSV asal Karawang teramplifikasi menggunakan primer spesifik protein selubung PRSV-P. Berdasar kisaran inangnya ada 2 strain PRSV, yaitu PRSVW dan PRSV-P. Strain PRSV-W hanya dapat menginfeksi tanaman dari famili Cucurbitaceae (Gonsalves 1998), sedangkan strain PRSV-P menginfeksi famili Caricaeae dan Cucurbitaceae. Oleh karena PRSV dapat teramplifikasi dengan primer spesifik PRSV-P hal ini menunjukkan PRSV pada tanaman mentimun disebabkan oleh PRSV-P, dan bukan PRSV-W, namun perlu dikonfirmasi dengan perunutan DNA.

Sampel asal Subang yang terdeteksi serologi dengan antiserum CABYV juga teramplifikasi dengan ukuran DNA $\pm 400 \mathrm{pb}$ menggunakan primer universal gen protein selubung genus Polerovirus. Ukuran DNA ini lebih pendek dibandingkan dengan DNA kontrol positif PeVYV (Pepper vein yellow virus) yang berukuran $\pm 600 \mathrm{pb}$ (Gambar $2 \mathrm{~b}$ ). Polerovirus menyebabkan gejala kuning pada tanaman mentimun (Knierim et al. 2010). Gejala kuning banyak ditemukan pada tanaman mentimun di tiga kabupaten di Jawa Barat. Gejala tersebut ikuti oleh vein banding seperti yang ditemukan di Kabupaten Bogor, Karawang, dan Subang. Anggota genus Polerovirus yang menginfeksi cucurbitaceae yaitu CABYV, MABYV (Melon aphid borne yellows virus), dan SABYV (Suakwa aphid borne yellow virus) (Lecoq et al. 1992; Knierim et al. 2010). Amplifikasi Polerovirus menggunakan primer universal PococpR dengan primer forward spesifik virus menghasilkan ukuran DNA CABYV, MABYV, dan SABYV berturut-turut adalah 700 pb, $450 \mathrm{pb}$, dan $950 \mathrm{pb}$ (Shang et al. 2012). Namun. amplifikasi Polerovirus dengan primer universal PL4F dan o3R menghasilkan amplikon yang lebih kecil dari $600 \mathrm{pb}$; diduga yang teramplifikasi non-spesifik DNA, sehingga perlu dikonfirmasi dengan primer spesifik CABYV dan perunutan DNA.

Gejala kuning yang teramati di tiga lokasi diikuti oleh beberapa gejala lain seperti mosaik, kerdil, dan keriting. Gejala yang terlihat pada tanaman mentimun diduga diinfeksi oleh Begomovirus. Deteksi PCR dilakukan terhadap sampel asal Subang dan Karawang yang menunjukan gejala kuning. Pita DNA Begomovirus teramplifikasi dengan ukuran DNA yang sama dengan kontrol positif ToLCNDV (Tomato leaf curl New Delhi virus) (Gambar 2c). Septariani et al. (2014) melaporkan ToLCNDV menginfeksi tanaman mentimun di Tegal, Sleman, Sukoharjo, dan Bogor. ToLCNDV juga ditemukan di Kabupaten Subang, Jawa Barat (Haerunisa et al. 2016). Spesies Begomovirus lainnya yakni SLCCNV (Squash leaf curl China virus) dilaporkan menginfeksi tanaman mentimun di Bali (Wiratama et al, 2015). Untuk mengetahui spesies virus DNA yang teramplifikasi, perlu dilakukan konfirmasi dengan perunutan DNA.

Deteksi RT-PCR terhadap sampel CGMMV dan WMV belum berhasil teramplifikasi. Sampel yang tidak berhasil teramplifikasi dapat disebabkan beberapa faktor, yaitu kualitas DNA yang kurang baik, tidak terdapat kesesuaian antara basa nukleotida target dengan basa nukleotida penyusun primer, virus yang diamplifikasi bukan merupakan virus target (Padmalatha dan Prasad 2006), dan kondisi penyimpanan sampel yang kurang baik sehingga RNA terdegredasi (Grisoni et al. 2006). Selain itu, reaksi silang (cross reaction) dalam uji serologi sering terjadi khususnya pada antiserum poliklonal. Antiserum poliklonal mampu mendeteksi spesies virus lain dalam genus yang sama atau yang memiliki kedekatan secara genetik (Rahim et al. 2015; Boben et al. 2007). CGMMV dan WMV positif terdeteksi pada sampel yang diuji, namun tidak teramplifikasi dengan RT-PCR dengan primer spesifik CGMMV dan universal Potyvirus. Untuk memastikan spesies virus, perlu dideteksi dengan primer universal Tobamovirus untuk sampel yang positif secara serologi dengan antiserum CGMMV dan primer spesifik anggota potyvirus lainnya dan perunutan DNA.

\section{KESIMPULAN}

Diagnosis virus pada mentimun tidak dapat ditentukan hanya berdasarkan gejala karena gejala yang ditemukan bervariasi. Virus pada tanaman mentimun terdeteksi disebabkan oleh CABYV, CGMMV, CMV, PRSV, SqMV, WMV, dan ZYMV yang secara umum menginfeksi secara campuran. CABYV, CGMMV, dan CMV merupakan virus yang dominan dengan frekuensi yang tinggi terdeteksi di lapangan. Semua virus yang terdeteksi telah menyebar pada pertanaman mentimun di tiga kabupaten di Jawa Barat. CABYV (Polerovirus) dan CGMMV merupakan virus yang masih baru ditemukan di Jawa Barat Indonesia, namun perlu dilakukan perunutan DNA untuk konfirmasi identitas genetiknya.

\section{DAFTAR PUSTAKA}

Ali, A., O. Mohammad, A. Khattab. 2012. Distribution of viruses infecting cucurbit crops and isolation of potential new virus-like sequences from weeds in Oklahoma. Plant Dis. 96:243-248.

Asniwita, S.H. Hidayat, G. Suastika, S. Susanto, S. Sujiprihati. 2013. Penggunaan galur lemah Chili veinal mottle virus untuk Proteksi silang. J Fitapatol Indones. 9(5): 145-152.

Boben, J., N. Mehle, M. Pirc, I.M. Plesko, M. Ravnikar. 2007. New molecular diagnostic methods for detection of Chrysanthemum stem necrosis virus (CSNV). ABS. 50(1):41-51.

[BPS] Badan Pusat Statistik. 2013. Produksi sayuran di Indonesia, 1997-2013 [Internet]. Jakarta (ID): Badan Pusat Statistik; [diunduh 2014 April 17]. Tersedia pada:

http://www.bps.go.Id/tab_sub/view.Php?kat=3\&tabel $=1$ \&daftar $=1 \&$ id_subyek $=55 \&$ notab $=70$. 
Correa, R.L., T.F. Silva, Sim Oes-Ara Ujo, P.A.V. Barroso, M.S. Vidal, M.F.S. Vaslin. 2005. Molecular characterization of a virus from the family Luteoviridae associated with cotton blue disease. Arch Virol. 150: 1357-1367.

Coutts, B.A., R.A.C. Jones. 2005. Incidence and distribution of viruses infecting cucurbit crop in the Northem Territory and Western Australia. Australian J Agric Res. 56(8):847-858.

Doyle, J.J., J.L. Doyle. 1990. Isolation of plant DNA from fresh tissue. Focus 22(1):13-15.

Gonsalves, D. 1998. Control of Papaya ringspot virus in papaya. Phytopathology 36:15-37.

Grisoni, M., M. Moles, K. Farreyrol, L. Rassaby, R. Davis, M. Pearson. 2006. Identification of Potyvirus infecting vanilla by direct sequencing of a short RTPCR amplicon. Plant Pathol. 55:523-529.

Haerunisa, R., G. Suastika, T.A. Damayanti. 2016. Identifikasi Begomovirus yang Berasosiasi dengan Penyakit Kuning Pada Mentimun di Jawa Barat dan Bali. J Horti Indonesia. 7 (1): 9-20.

Hidayat, S.H., S. Nurulita, S. Wiyono. 2012. Infeksi Pepaya ring spot virus pada tanaman pepaya di Nangroe Aceh Darussalam. J Firopatol Indones. 8(6): 184-187.

Knierim, D., T.C. Deng, W.S. Tsai, K.S. Green, L. Kenyon. 2010. Molecular identification of three distinct Polerovirus species and a recombinant Cucurbit aphid borne yellows virus strain infecting cucurbit crops in taiwan. Plant Pathol. 59:991-1002.

Letschert, B., G. Adam, D. Lesemann, P. Willingmann, C. Heinze. 2001. Detection and differentiation of serologically cross-reacting tobamoviruses of Economical importance by RT-PCR and RT-PCRRFLP. J Virol Methods.10 6(1):1-10.

Lecoq, H, D. Bourdin, S. Wipf, C. Bon, Lot, O. Lemaire, E. Herrbach. 1992. A new yellowing disease of cucurbits caused by a luteovirus, Cucurbit aphidborne yellows virus. Plant Pathol. 41(6):749-761.

Li, R., S. Salih, S. Hurtt. 2004. Detection of Geminiviruses in Sweetpotato by Polymerase Chain Reaction. Plant Dis. 88:1347-1351.

Marie-Jeanne, V., R. Loos, J. Peyre, B. Alliot, P. Signoret. 2000. Differentiation of Poaceae potyviruses by reverse transcription-polymerase chain reaction and restriction analysis. J Phytopathol. 148: 141-151.

Moekasan, T.K., L. Prabaningrum, W. Adiyoga, D.P. Putter. 2014. Panduan Praktis Budidaya Mentimun
Berdasarkan Konsep Pengendalian Hama Terpadu (PHT). Jakarta (ID): Penebar Swadaya.

Mohammed, H., A. Manglli, S. Zicca, A. El Hussein, M. Mohamed, L. Tomassoli. 2012. First Report of Papaya Ring spot Virus in Sudan. New Dis Rep.26:26

Moradi, Z., B. Jafarpour. 2010. Mixed infections of Watermelon mosaic potyvirus and Cucumber green mottle mosaic tobamovirus in cucurbit hosts. Plant Prot J. 2(4):353-365.

Padmalatha, K., M.N.V. Prasad. 2006. Optimation of DNA isolation and PCR protocol for RAPD analysis of selected medicinal and aromatic plants of conservation on concern from penisular India. African J Biotech. 5(3):230-234.

Poolpol, P., T. Inouye. 1986. Enhancement of cucumber mosaic virus multiplication by Zucchini yellow mosaic virus in doubly infected cucumber plants. Phytopathol Soc Japan. 52:22-30.

Rahim, Y.F., T.A. Damayanti, M. Ghulamahdi. 2015. Deteksi virus yang menginfeksi kedelai di Jawa. J Fitopatol Indones. 11(2): 59-67.

Rukmana. 1994. Budidaya Mentimun. Yogyakarta (ID): Kanisius.

Septariani, D.N., S.H. Hidayat, E. Nurhayati. 2014. Identifikasi Penyebab Penyakit Daun Keriting Kuning pada Tanaman Mentimun. J HPT Trop. 1(14):80-86.

Shang, Q., H. Xiang, D. Li, J. Yu, C. Han. 2012. Rapid detection an differentiation of Three Cucurbitinfecting Poleroviruses by Multiplex RT-PCR. J Agric Sci. 4(4): 209-2016.

Syller, J. 2012. Facilitative and antagonistic interaction between plant viruses in mix infection. Mol Plant Pathol. 13(2):204-216.

Shtayeh, M.S.A., R.M. Jamous, E.Y. Husein, M.Y. Alkhader. 2010. First report of squash leaf curl in squash (Cucurbita pepo), melon (Cucumis melo), and cucumber (Cucumber sativus) in the Northern West Bank of the Palestinan Authority. American Phytopathol Soc. 94(5): 640.

Wiratama, I.D.M.P., G.N.A.S. Wirya, N.N.P. Andyani, Nyana IDN, Suastika G. 2015. Laporan Pertama Infeksi Begomovirus Pada Mentimun di Bali. J Fitopatol Indones 11 (5): 175-178. 
Zhang, X.S., J. Holt. 2001. Mathematical models of cross protection in the epidemiology of plant virus disease. Phytopathology 91:924-93 